\title{
Anal Adenocarcinoma Can Masquerade as Chronic Anal Fistula in Asians
}

\author{
Faith Qi-Hui Leong, Dedrick Kok Hong Chan, Ker-Kan Tan \\ Division of Colorectal Surgery, University Surgical Cluster, National University Health System, Singapore
}

Purpose: Perianal adenocarcinoma arising from a chronic anorectal fistula is a rare condition for which the natural history and optimal management are not well established. For that reason, we conducted a retrospective analysis of 5 consecutive patients with a perianal adenocarcinoma arising from a chronic anorectal fistula managed at our institution from January 2014 to December 2015.

Methods: The patients were identified from a prospectively collected colorectal cancer database that included all patients managed for colorectal cancer at our institution.

Results: The median age at diagnosis was 64 years (range, 55-72 years). Magnetic resonance imaging (MRI) was the initial investigation for all patients and showed a hyperintense T2-weighted image. One patient underwent an abdominoperineal resection following neoadjuvant chemoradiotherapy and remained disease free during the 12-month follow-up. Three patients received neoadjuvant therapy with intent for surgery, but did not undergo surgery due to either worsening health or metastatic spread. One patient declined intervention. The median overall survival was 10.5 months (range, 2-19 months). Conclusion: A high index of suspicion is required to make a clinical diagnosis of an anal adenocarcinoma arising from a chronic fistula. Histologic diagnosis must be achieved to confirm the diagnosis. Multimodal therapy with neoadjuvant chemoradiotherapy followed by abdominoperineal resection is the treatment of choice.

Keywords: Anal adenocarcinoma; Chronic inflammation; Anal fistula; Diagnosis

\section{INTRODUCTION}

An anal adenocarcinoma is an extremely uncommon disease entity that has been postulated to arise from chronic inflammation, such as the inflammation in patients with Crohn disease and/or an anal fistula [1]. Moreover, it is thought to originate from the columnar epithelium lining the anal glands [2]. Owing to its rarity, the natural history and optimal management of this disease is not well established, leading to challenges to clinicians. Firstly, a high index of suspicion is required to establish the disease as it

Received: June 25, 2017 - Accepted: March 15, 2018

Correspondence to: Dedrick Kok Hong Chan, MBBS, FRCS

Division of Colorectal Surgery, University Surgical Cluster, National

University Health System, 1E Kent Ridge Road, 119228 Singapore

Tel: +65-67724235, Fax: +65-67778206

E-mail: dedrick_kh_chan@nuhs.edu.sg

ORCID code: https://orcid.org/0000-0002-4237-8648

(C) 2019 The Korean Society of Coloproctology

This is an open-access article distributed under the terms of the Creative Commons Attribution NonCommercial License (http://creativecommons.org/licenses/by-nc/4.0) which permits unrestricted noncommercial use, distribution, and reproduction in any medium, provided the original work is properly cited. may often mimic other benign conditions such as anal fissures and fistulae [3]. Following diagnosis and staging, the best treatment strategy has not been established; in particular, the timing of surgery relative to adjuvant treatment and whether short- or longcourse chemotherapy is associated with the best outcomes have not been determined. For these reasons, we present our experience in the management of five patients with an adenocarcinoma arising from chronic inflammation due to a chronic anal fistula, highlighting and discussing the clinical presentations, evaluations, and management of those patients.

\section{METHODS}

A retrospective analysis of 5 consecutive patients with a perianal adenocarcinoma associated with a chronic anorectal fistula managed in our institution from January 2014 to December 2015 was performed. The patients were identified from a prospectively collected colorectal cancer database that included all patients managed for colorectal cancer at our institution. Data collected included basic demographic information, symptoms on initial pre- 
sentation, laboratory and radiographic reports, intraoperative and clinic notes, and clinical progress on follow-up.

\section{RESULTS}

Five male patients with a median age of 64 years (range, 55 to 72 years) were included in this study. All of them presented with symptoms of a painful enlarging perianal mass. None of the patients had inflammatory bowel disease. Three of the five patients also had symptoms of perianal discharge and fever while the other 2 presented with per rectal bleeding. Some of the clinical signs included a palpable anorectal/perineal mass or perianal skin induration with multiple external openings.

Magnetic resonance imaging (MRI) was performed for all 5 patients and demonstrated hyper-intense lesions on the T2-weighted phase (Fig. 1). Two of these MRIs were reported as having features consistent with an abscess while one patient was found to have a large contained perforation of the distal rectum. Only 2 patients highlighted a suspicion of malignancy initially. Although endoscopic evaluation was performed for all 5 patients, 3 still required an examination under anesthesia (EUA) procedure to obtain histologic confirmation of the adenocarcinoma.

After discussions of the 5 patients at the Multidisciplinary Tumor Board following computed tomographic scans of the abdomen and pelvis to evaluate for systemic disease, 1 of the 5 patient underwent a laparoscopic abdominoperineal resection following a short course of neoadjuvant radiotherapy while three under- went neoadjuvant chemoradiotherapy followed by planned surgery. Of these 3 patients, only one underwent an open abdomino-

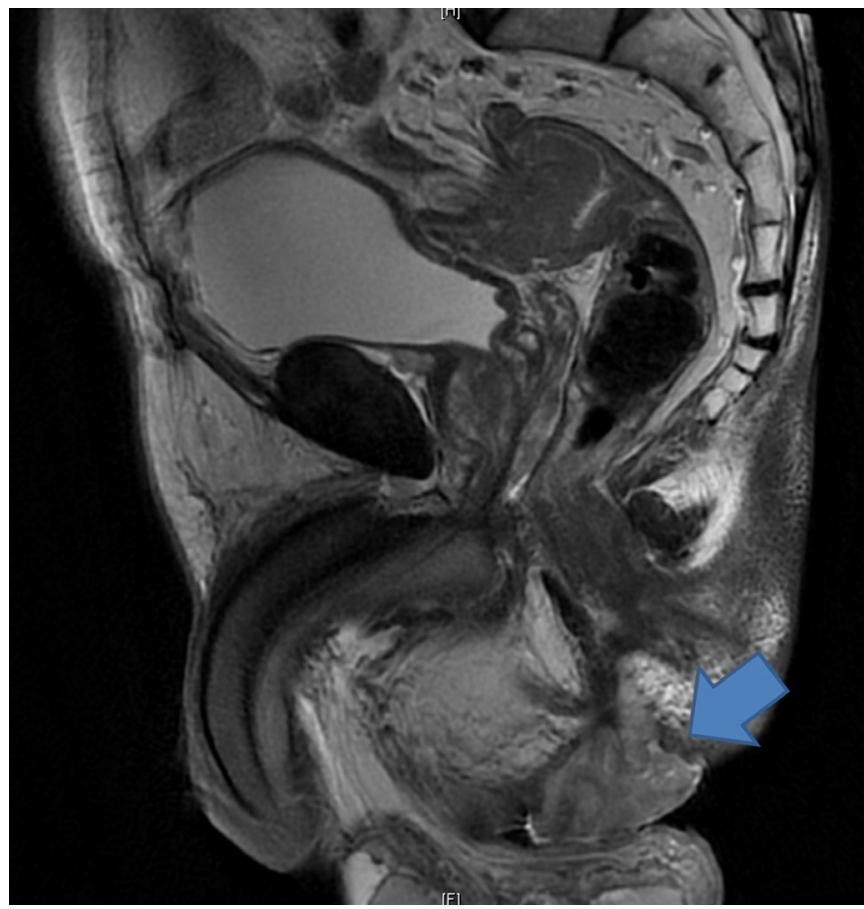

Fig. 1. Magnetic resonance imaging demonstrating a chronic perineal lump. The arrow corresponds to the perineal lump.

Table 1. Demographic and clinical characteristics of patients with chronic anorectal fistula

\begin{tabular}{|c|c|c|c|c|c|c|c|c|c|c|}
\hline No. & $\begin{array}{l}\text { Age } \\
(\mathrm{yr}) / \\
\text { sex }\end{array}$ & $\begin{array}{l}\text { Duration } \\
\text { of symp- } \\
\text { toms (yr) }\end{array}$ & $\begin{array}{l}\text { Presentation of } \\
\text { perianal } \\
\text { adenocarcinoma }\end{array}$ & $\begin{array}{l}\text { Investigations } \\
\text { (Imaging/endo- } \\
\text { scopic/EUA) }\end{array}$ & CEA & $\begin{array}{l}\text { No. of false } \\
\text { negative } \\
\text { histologies }\end{array}$ & $\begin{array}{l}\text { Histologic } \\
\text { diagnosis/stage } \\
\text { of disease }\end{array}$ & Treatment & $\begin{array}{l}\text { Outcome/ } \\
\text { pattern of } \\
\text { failure }\end{array}$ & $\begin{array}{l}\text { Duration from } \\
\text { diagnosis to } \\
\text { death or last } \\
\text { follow-up (mo) }\end{array}$ \\
\hline 1 & $67 / M$ & 2 & $\begin{array}{l}\text { Lump at anus, per } \\
\text { rectal bleeding }\end{array}$ & $\begin{array}{l}\text { MRI pelvis, CT } \\
\text { TAP/colonos- } \\
\text { copy/EUA }\end{array}$ & 6.7 & 1 & $\begin{array}{l}\text { Mucinous adeno- } \\
\text { carcinoma/ } \\
\text { T3N1M0 }\end{array}$ & $\begin{array}{l}\text { Neoadjuvant radiotherapy } \\
\text { Abdominoperineal resection } \\
\text { Adjuvant chemotherapy }\end{array}$ & $\begin{array}{l}\text { Alive/no } \\
\text { recurrence }\end{array}$ & 12 \\
\hline 2 & $60 / M$ & 11 & $\begin{array}{l}\text { Perianal discharge, } \\
\text { pain, fever }\end{array}$ & $\begin{array}{l}\text { MRI pelvis, CT } \\
\text { TAP/flexible } \\
\text { sigmoidoscopy/ } \\
\text { EUA }\end{array}$ & 8.2 & 2 & $\begin{array}{l}\text { Mucinous adeno- } \\
\text { carcinoma/ } \\
\text { T4bNOMO }\end{array}$ & Abdominoperineal resection & $\begin{array}{l}\text { Death from } \\
\text { metastatic } \\
\text { disease }\end{array}$ & 19 \\
\hline 3 & $72 / \mathrm{M}$ & 5 & $\begin{array}{l}\text { Lump at anus, } \\
\text { perianal pain and } \\
\text { discharge, per rectal } \\
\text { bleeding }\end{array}$ & $\begin{array}{l}\text { MRI pelvis, CT TAP/ } \\
\text { colonoscopy }\end{array}$ & 12.1 & 0 & $\begin{array}{l}\text { Adenocarcinoma, } \\
\text { no mucinous } \\
\text { component/ } \\
\text { T4NOM0 }\end{array}$ & Chemoradiotherapy & $\begin{array}{l}\text { Death from } \\
\text { metastatic } \\
\text { disease }\end{array}$ & 5 \\
\hline 4 & $55 / M$ & 3 & $\begin{array}{l}\text { Pain and swelling } \\
\text { over right gluteal } \\
\text { region with } \\
\text { discharge }\end{array}$ & $\begin{array}{l}\text { MRI pelvis/ } \\
\text { colonoscopy/ } \\
\text { EUA }\end{array}$ & ND & 0 & $\begin{array}{l}\text { Mucinous adeno- } \\
\text { carcinoma/ } \\
\text { T3N1M1 }\end{array}$ & Nil & $\begin{array}{l}\text { Metastatic } \\
\text { disease/ } \\
\text { lost to } \\
\text { follow-up }\end{array}$ & 2 \\
\hline 5 & $64 / \mathrm{M}$ & 2 & $\begin{array}{l}\text { Lump at anus, } \\
\text { perianal discharge } \\
\text { and pain }\end{array}$ & $\begin{array}{l}\text { MRI pelvis, } \\
\text { CT TAP/ } \\
\text { colonoscopy }\end{array}$ & ND & 0 & $\begin{array}{l}\text { Mucinous adeno- } \\
\text { carcinoma/ } \\
\text { T4NOMO }\end{array}$ & Chemoradiotherapy & $\begin{array}{l}\text { Developed } \\
\text { AMI/not fit } \\
\text { for surgery }\end{array}$ & 16 \\
\hline
\end{tabular}

EUA, examination under anesthesia; CEA, carcinoembryonic antigen; MRI, magnetic resonance imaging; CT TAP, computed tomography of thorax, abdomen, and pelvis; $\mathrm{ND}$, not done; $\mathrm{AMl}$, acute myocardial infarction. 
perineal resection subsequently, another developed disseminated metastatic disease upon completion of the neoadjuvant treatment, and the last developed an acute myocardial infarction and heart failure and was deemed unfit to undergo a major resection. The last of the five patients had metastatic disease on presentation and was offered chemotherapy; that patient declined all treatment and was lost to follow-up 4 months after initial presentation. These findings are summarized in Table 1.

\section{DISCUSSION}

The pathogenesis for anal adenocarcinomas is postulated to be due to chronic inflammation leading to persistent mucosal regeneration [4]. A long leadtime of about 10 years is deemed the minimum time necessary for malignant change to occur under chronic inflammatory conditions. The diagnosis of an anal adenocarcinoma requires a high index of suspicion, especially in patients with a long history of symptoms arising from a fistula and the corresponding signs of an anal lump [5].

A histological diagnosis is definitely necessary to confirm the diagnosis and thence for treatment to be initiated. As some anal adenocarcinomas have mucinous features, superficial biopsies are often inadequate as these mucinous tumors form mucin lakes in the submucosa and muscularis propria layers [6]. Several of our patients required EUA procedure to obtain more extensive biopsies to achieve the diagnosis. Therefore, a histologic examination of samples to aid in the diagnosis is important for all patients undergoing surgery for a chronic anal fistula.

The use of MRI to establish malignant transformation appears promising, but still requires the validation of large-scale studies. MRI allows for superior anatomic delineation. Mucinous adenocarcinomas exhibit low signal intensity on T1-weighted imaging and high signal intensity on T2-weighted imaging. Mucinous lakes reflecting the mucinous nature of the adenocarcinoma may also be visualized as heterogeneous hyperintense granules of varying sizes on T2-imaging [7]. Endoanal ultrasound, computed tomography, and positron emission tomography have been shown to have low sensitivity for different chronic inflammations from malignant transformation [8].

Once the diagnosis has been confirmed, a multidisciplinary approach is preferred due to the complexity of the condition. Neoadjuvant chemoradiotherapy has been reported to be promising in the management of this condition, with Hongo et al. [9] reporting $85 \%$ complete response after neoadjuvant therapy. A large ret- rospective study done by the Rare Cancer Network reported 5 -year disease-free survival rates of $54 \%$ vs. $22 \%$ in patients who had undergone neoadjuvant treatment and surgery compared with surgery alone [10].

\section{CONFLICT OF INTEREST}

No potential conflict of interest relevant to this article was reported.

\section{REFERENCES}

1. Kline RJ, Spencer RJ, Harrison EG Jr. Carcinoma associated with fistulainano. Arch Surg 1964;89:989-94.

2. Abramson DJ. Perianal mucinous adenocarcinoma and fistulainano. Mil Med 1986;151:543-6.

3. Klas JV, Rothenberger DA, Wong WD, Madoff RD. Malignant tumors of the anal canal: the spectrum of disease, treatment, and outcomes. Cancer 1999;85:1686-93.

4. Nelson RL, Prasad ML, Abcarian H. Anal carcinoma presenting as a perirectal abscess or fistula. Arch Surg 1985;120:632-5.

5. Skir I. Mucinous carcinoma associated with fistulas of longstanding. Am J Surg 1948;75:285-9.

6. Maejima T, Kono T, Orii F, Maemoto A, Furukawa S, Liming W, et al. Anal canal adenocarcinoma in a patient with longstanding Crohn's disease arising from rectal mucosa that migrated from a previously treated rectovaginal fistula. Am J Case Rep 2016;17: 448-53.

7. Yamaguchi T, Kagawa R, Takahashi H, Takeda R, Sakata S, Nishizaki D. Diagnostic implications of MR imaging for mucinous adenocarcinoma arising from fistula in ano. Tech Coloproctol 2009;13:251-3.

8. Gecse KB, Bemelman W, Kamm MA, Stoker J, Khanna R, Ng SC, et al. A global consensus on the classification, diagnosis and multidisciplinary treatment of perianal fistulising Crohn's disease. Gut 2014;63:1381-92.

9. Hongo K, Kazama S, Sunami E, Kitayama J, Watanabe T. Perianal adenocarcinoma associated with anal fistula: a report of 11 cases in a single institution focusing on treatment and literature review. Hepatogastroenterology 2013;60:720-6.

10. Belkacémi Y, Berger C, Poortmans P, Piel G, Zouhair A, Méric JB, et al. Management of primary anal canal adenocarcinoma: a large retrospective study from the Rare Cancer Network. Int J Radiat Oncol Biol Phys 2003;56:1274-83. 